\title{
Fixed Bed Nuclear Reactor Concept
}

\author{
Farhang Sefidvash \\ Nuclear Engineering Department, Federal University of Rio Grande do Sul, Porto Alegre, Brazil \\ farhang@ufrgs.br http://www.rcgg.ufrgs.br/fbnr.htm
}

\begin{abstract}
Small nuclear reactors without the need for on-site refuelling have greater simplicity, better compliance with passive safety systems, and are more adequate for countries with small electric grids and limited investment capabilities. The Fixed Bed Nuclear Reactor (FBNR) is based on the Pressurized Water Reactor (PWR) technology. FBNR is an integrated primary circuit and simple in design. It has the characteristics of being small, modular, inherently safe and passively cooled reactor with reduced adverse environmental impact. The spherical fuel elements are fixed in the suspended core by the flow of water coolant. Any accident will signal cutting off of power to the coolant pump causing a stop in the flow. These results in making the fuel elements fall out of the reactor core by the force of gravity and become stored in the passively cooled fuel chamber under subcritical condition. Therefore, the simplicity and passive safety characteristics of the reactor in the ambit of a well dominated technology, makes it a viable option for the near future deployment.
\end{abstract}

\section{Introduction}

The Fixed Bed Nuclear Reactor (FBNR) is a simplified version of the fluidized bed nuclear reactor concept [1-75]. In this reactor the spherical fuel elements are at a fixed position in the core thus there is no concern about the consequences of frictions between the fuel elements that may be raised about the fluidized bed concept. In that case there is a need to study the degree of erosion in order to consider in determining the clad thickness. There is little work done on the fixed bed nuclear reactor concept so far, but the experience gained from the fluidized bed reactor will greatly facilitate the development of the fixed bed concept.

\section{Reactor description and applications}

The FBNR is based on the Pressurized Water Reactor (PWR) technology. The reactor is modular in design and each module is fuelled in the factory thus the fuelled modules in the sealed form are transported to and from the site. FBNR has long fuel cycle time and therefore there is no need forof refuelling the reactor on site. 
The Fixed Bed Nuclear Reactor is modular in design such that any size of reactor can be constructed from the basic module. It is an integrated primary system design. The basic module has in its upper part the reactor core and a steam generator and in its lower parts the fuel chamber. The core consists of a $25-\mathrm{cm}$ diameter zircaloy tube in which, during the reactor operation, the spherical fuel elements are held together by the coolant flow in a fixed bed configuration forming a suspended core. The fuel chamber is a $10-\mathrm{cm}$ diameter tube made of high neutron absorbing alloy, which is directly connected underneath the core tube. A steam generator of the shell and tube type is integrated into the upper part of the module. A thin neutron absorber shell slides inside the core tube, acting similar to a control rod. The reactor is provided with a pressurizer system to keep the coolant at a constant pressure. Each module has independently a pump. A crown type header on the top of the reactor joins and connects all the modules to a common system where the entering and outgoing fluids are integrated into a unique system.

The pump circulates the coolant inside the module moving up through the fuel chamber, the core, and the steam generator and thereafter flows back down to the pump through the concentric annular passage. At a certain pump velocity, the water coolant carries up the $8 \mathrm{~mm}$ diameter spherical fuel elements from the fuel chamber into the core. A fixed suspended core in the upper part of the module is formed. In the shut down condition, the suspended core breaks down and the fuel elements leave the core and fall back into the fuel chamber.

Any signal from any detector due to any type of accident will cut-off power from the pump, causing the fuel elements to leave the core and fall back into the fuel chamber by the force of gravity, where they remain in a highly subcritical and passively cooled condition. The fuel chambers are cooled by natural convection transferring heat to the surrounding air or to a pool of water.

A detailed heat transfer analysis of the fuel elements has shown that due to a high convective heat transfer coefficient and a large heat transfer surface to volume ratio, the maximum power extracted from the reactor core is not limited to the material temperature limits, but to the mass flow of the coolant corresponding to the allowed pumping power ratio. The core tube is designed in a slightly conical shape in order to decrease the coolant velocity along the height of the reactor, thus causing a compacting effect and securing a stable fixed bed.

The proposed reactor concept is very flexible in nature, and makes devising of many types of designs possible such as follows:

\subsection{Fixed bed with supercritical steam as coolant}

The concept of a direct cycle reactor operating at supercritical pressure is attractive for improving the thermal efficiency drastically to enhance the resulting environmental protection. The reactor combines the fixed bed concept with the idea of using direct cycle reactor operating at supercritical pressure proposed by Oka [76]. The supercritical steam is used as the reactor coolant. The critical pressure of water is 221 bar. When the reactor operates at $250 \mathrm{bar}$, the supercritical water does not exhibit a change in phase and the concept of boiling does not exist. The water density decreases continuously with temperature.

The coolant entering temperature, on the lower part of the bed, is $310^{\circ} \mathrm{C}$ and the exit temperature, 
on the upper part of the bed, is $416^{\circ} \mathrm{C}$. Therefore, the water density decreases continuously from 0.725 to $0.137 \mathrm{~g} / \mathrm{cm}^{3}$ along the bed. This is an important factor in causing the bed to become a more compact and having fixed core. The recommended pressure of 250 bars is due to the smooth and mild variation of density with pressure in this region resulting in stability of flow in the core. The power production is much higher in this option as the difference in inlet and outlet enthalpy is much higher than a simple pressured or even boiling reactor. The plant thermal efficiency is estimated to exceed $40 \%$. The turbines will be smaller compared with the light water reactors by adopting the supercritical steam as the coolant. The superheated steam is fed directly into the turbine. The steam-water separation is not needed for direct cycle reactor. Some other advantages of such a choice besides the high thermal efficiency, will have smaller turbine, no steam generators, and reduced waste heat.

\subsection{Fixed bed with helium gas as coolant}

In this option, the fixed bed is cooled by helium gas yielding all the advantages of a gas cooled reactor including high efficiency and utilization of direct gas turbine. In this case we have a fast nuclear reactor system.

\subsection{Fluidized bed with water as coolant}

The power density may significantly be increased by fluidizing the bed. The increase in turbulence of the coolant will allow a significant increase in power generation. In this case the effects of flow on the homogeneity of the fluidized bed porosity and physical interaction between fuel elements need to be further studied.

\subsection{Fluidized bed with supercritical steam as coolant}

This option still takes advantage of further increase in heat transfer rate and higher temperature steam production leading to still a more efficient system.

\section{Special features of FBNR}

The reactor is shop fabricated and has no large or heavy components. The safety features of the reactor allow it to be built within or near urban areas. The long fuel life of the reactor makes it appropriate for isolated remote places without infrastructure. It can supply energy to the floating power plant. The reactor is equally appropriate for electricity generation, district heating, seawater desalination, process steam production, or any such combined applications.

The combination of a nuclear power reactor with water desalination plant can most economically be utilized because the higher the temperature and pressure of steam used in a turbine, the lower the cost of electricity produced. For fractional distillation, on the other hand, steam at low temperature and pressure is needed and the greater part of input heat is the latent heat of steam. Therefore, the power production and desalination systems may be advantageously combined. A 100 MWe FBNR power plant when employed in a dual purpose plant for producing both power and water will produce $70 \mathrm{MWe}$ of electricity and about $130,000 \mathrm{~m}^{3} /$ day of desalinated water. 


\section{Major design and operating characteristics}

The thermal production is about $30 \mathrm{Mwt}$ per module. The power production depends on the choice made in respect to the power fraction allowed to feed the coolant pump. The reactor can be designed to produce double or triple of this power and to be load following or simply to operate on the base load regime.

There are two options are envisaged for the fuel elements. One the zircaloy cladded uranium dioxide spherical fuel pellets, and the other spherical fuel elements made from TRISO type coated particles. The enrichment for theUO2 option is about 3\% and for the coated particle is about $8 \%$. The coolant and moderator are light water. In the coated particle option, graphite also contributes to the neutron moderation. The module size will depend on the fuel type used and the enrichment allowed. For example, for a water cooled uranium dioxide fuelled reactor, the core module diameter is $25 \mathrm{Cm}$. In the case of using coated fuel particles, the core tube may need to be larger.

In the UO2 option, the typical values for reactor parameters are similar to the ones for conventional pressurized water reactors. FBNR is essentially a PWR with spherical fuel elements instead of cylindrical ones having a harder neutron spectrum. The moderator to fuel volume ratio in FBNR is about 0.8 in comparison to about 2 in the conventional PWR.

The reactor does not use burnable poison and the reserve reactivity is the fuel, which remains in the fuel chamber outside the core. For long time reactivity insertion, the fuel is allowed to enter the core by lifting up the core height limiter. The absorber shell is used for fine and short time reactivity control.

The pressurized water cooled reactor operating at 160 bars with inlet/outlet temperatures of 290 and $326 \mathrm{C}$. will have about $33 \%$ efficiency, but the reactor cooled by supercritical steam will produce an efficiency of more than $40 \%$.

The high ratio of surface to volume ratio for spherical fuel elements causes excellent heat transfer conditions resulting in low maximum to average fuel temperatures. In the case of the coated fuel particles, the situation is still more favourable as the fuel stands at very high temperatures. The coolant flow rate is about $16 \mathrm{Cm} / \mathrm{sec}$. The core is cooled by forced convection, but the residual heat produced in the fuel chamber is cooled by natural convection.

\section{Fuel Options}

There are wo options are proposed for the FBNR fuel elements:

1. A $8 \mathrm{~mm}$ diameter spherical fuel element made of uranium dioxide with the density of 10.5 $\mathrm{g} / \mathrm{cm} 3$, cladded by zircaloy.

2. A $8 \mathrm{~mm}$ diameter spherical fuel element made of compacted Micro-Fuel-Elements (MFE) with the density of $5.9 \mathrm{~g} / \mathrm{cm} 3$, cladded by silicon carbide. 
MFE are coated particles and are similar to TRISO fuel with outer diameters about $2 \mathrm{~mm}$. They consist of $1.5-1.64 \mathrm{~mm}$ diameter uranium dioxide spheres coated with 3 layers. The inner layer is of $0.09 \mathrm{~mm}$ thick porous pyrolytic carbide (PYC) with density of $1 \mathrm{~g} / \mathrm{cm} 3$ called a buffer layer, providing space for gaseous fission products. The second layer is of $0.02 \mathrm{~mm}$ thick dense PYC (density of $1.8 \mathrm{~g} / \mathrm{cm} 3$ ) and the outer layer is $0.07-0.1 \mathrm{~mm}$ thick corrosion resistant silicon carbide (SiC). Ceramic protection films, manufactured by chemical vapor deposition (CVD) method, create resistance of graphite components against water and steam at high temperatures $\left(450^{\circ}-550^{\circ} \mathrm{C}\right.$ at normal operating conditions and up to $1400^{\circ} \mathrm{C}$ at accidental conditions ). Small fuel elements are able to confine fission products indefinitely at a temperature less than $1400^{\circ} \mathrm{C}$.

In order to create additional inhibition to power excursion, the isotopes of $\mathrm{Lu}^{175} / \mathrm{Lu}^{176}$ or $\mathrm{Ta}^{181} / \mathrm{Ta}^{182}$ may be added to the fuel. Harms [78] argue that introducing a large Doppler effect isotope such as tantalum $\left(\mathrm{Ta}^{181}\right)$ into the fuel, in the case of a power excursion it absorbs much neutrons producing $\mathrm{Ta}^{182}$ which in turn having a large neutron capture cross section absorbs still more neutrons. This tandem effect must further be studied.

\section{Technical features and technological approaches}

\subsection{Economics and maintainability}

The simplicity of design, short construction period, and the reactor being modular in design, result in much smaller capital investment compared to a conventional PWR. The provision of small units match the energy needs as they arise, instead of providing large units to meet the uncertain energy requirements of the future. This will avoid the necessity of a large present investment thus simplifying the raising of the needed funds.

The elimination of on-site refuelling and long core life reduces the operation and maintenance costs of the reactor. The lack of burnable poison contributes greatly to the neutron economy and thus requires lower fuel enrichment. The simplicity of fabrication of fuel elements for FBNR compared, for example, to the fuel assembly in a PWR contributes to reduced costs.

The inherent safety feature of the reactor allows the possibility of having it operate totally by computers avoiding human operating errors and reducing costs. Only an inspection and maintenance group is required to periodically do check up and maintenance of various reactors located in different localities.

The total electrical energy production cost from the FBNR is estimated at 21 in $\$ / M W h$ unit. The capital cost being about 16, the fuel cost 3, and the operation cost of 2 . This cost value does compete well with alternative energy sources. The reactor being small, shop fabricated, requiring short construction period of about 2 years, involves relatively small investment of about 1000 $\$ /$ Kwe, and meets the incremental increase in energy demands, thus making it an attractive capital investment.

The total investment requirement to design, construct, and commission the FBNR including investment during construction, is such that the necessary investment funds can easily be raised. 
The risk of investment in FBNR is sufficiently low to be acceptable to investors compared to the risk of investment in other energy projects. The FBNR by its nature is a good long-term investment opportunity.

\subsection{Provisions for sustainability, waste management, and minimum adverse environmental impacts.}

The inherent safety feature and smallness of the reactor make it impossible to have a large release of radioactivity to the environment. However, the envisaged simple underground containment will, as a defense-in-depth measure, protect the environment against any possible adverse event.

The various options for FBNR make the utilization of all types of fissile and fertile materials such as uranium, plutonium, and thorium possible. This allows that besides uranium one uses plutonium resulting from the dismantling of nuclear weapons and the enormous quantity of thorium available in countries like Brazil and India. Therefore, the fuel resources for FBNR are sufficient for centuries if not for thousands of years.

The spent fuel from FBNR is in a form and size that can directly be used as a source of radiation for irradiation purposes in agriculture and industry. Therefore, the spent fuel from FBNR may not be considered as waste, in a peaceful world of the future, as it can perform a useful function. They may be reprocessed similar to that of the LWR. Should reprocessing not be allowed, the spent fuel elements can easily be vitrified in the modules and the whole module be deposited directly in a waste repository. These factors result in reduced adverse environmental impact.

\subsection{Safety and Reliability}

The fuel elements in FBNR, due to the flow of coolant, form a suspended core, thus any motivation for an accident will cut the power from the coolant pump. Consequently, the fuel elements fall out of the core, by the force of gravity, back into the highly subcritical and passively cooled fuel chamber.

The FBNR fuel elements are much more robust than that of a PWR. They are simply loosely packed spherical fuel elements compared to the PWR fuel assemblies that are delicate structures involving grids and thimble rods. Therefore, there is no seismic effect on the FBNR fuel.

The FBNR fuel elements consist of small spheres where each one contain less than $0.25 \%$ of fuel that exists in a single fuel rod of a conventional PWR, thus any leakage from such a fuel element is of insignificant consequence. It is very difficult to imagine a scenario that these fuel elements can cause a major release of radioactivity, thus there is no need for any human relocation or evacuation measures.

The FBNR utilizes the PWR technology, thus all safety basis for it has already been well established by the IAEA and most national nuclear organizations. The computer codes to analyse the FBNR are the modified versions of those used for the design and analysis of the conventional pressurized light 
water reactors. A variety of such codes are available which have been successfully applied to the conventional PWR. Here, only the model of equivalence between a spherical and cylindrical fuel element needs to be verified. Testing on a single module can simply do this experimental verification. The test module simply consists of a pump and a $25 \mathrm{~cm}$ diameter tube that is partially filled with spherical fuel pellets. It is put in a PWR test facility and the necessary experiments and verifications are made. The prototype of the reactor will consist of a single module that can easily be built at a relatively low cost.

Transportation of the FBNR is much simpler than that of the PWR fuel assemblies. They are simply small spherical pellets instead of being about $4 \mathrm{~m}$ long fuel assemblies. The decommissioning of FBNR is relatively a simple job as it being modular in design, they are small in size and weight. There is no heavy pressure vessel.

A holistic life-cycle analysis of FBNR encompassing the effect on people and on the environment of entire integrated fuel cycle is easily performed. The inherent safety and passive cooling nature of the reactor before hand shows the safe results no matter what scenario is used.

\subsection{Proliferation resistance}

The irradiated coated particle fuel discharged from the reactor is very resistant against heat and nitric acid, thus it is difficult to reprocess. Reprocessing technology has not been developed yet for high temperature micro sphere fuel elements. It is not easy to acquire this technology. The commercial grade plutonium contained in spent MFE is less accessible than from standard LWR spent fuel.

Adopting a thorium cycle as an intrinsic measure will hinder the possibility of misuse of nuclear materials for nuclear weapons. The mixing of thorium with low enriched uranium or plutonium results in the production of U-233 that is diluted along with U-235 in U-238. The access to uranium will only be possible through isotope separation techniques. The high $\mathrm{Pu}-238$ to $\mathrm{Pu}-239$ ratio and the production of gamma emitting Tl-208 in the thorium cycle are hindrances to nuclear proliferation.

The proposed World Nuclear Energy Company (WONEC), an international consortium responsible for the development and deployment of FBNR will operate closely and faithfully under the auspices of IAEA to eliminate the problem of proliferation.

\subsection{Technical features and technological approaches used to facilitate physical protection.}

The fuel is contained in a sealed module inaccessible to outsiders. It can only be manipulated in the factory. Only under designed operating conditions the fuel remains in the core and the reactor can become critical, but under any other situations, the fuel leaves the core and remains in a subcritical state. Therefore, there is no scenario is envisaged where sabotage can provoke adverse consequences. 


\subsection{Non-technical factors and arrangements that could facilitate effective development and deployment of reactor installation.}

The existing nuclear power infrastructures and legal institutions can be used in deploying the proposed reactor concept. The reactor fulfills the objectives of electricity generation, steam production for industrial applications and water desalination.

It is desirable that an institution such as World Nuclear Energy Company (WONEC) be formed to become a catalyst in organizing and coordinating the world-wide existing and to-be-created scientific, technological and industrial elements in order to supply the world with clean and safe nuclear energy. WONEC can supply the world with the proposed inherently safe nuclear reactor and be responsible for its entire fuel cycle. It is to function as a commercial as well as scientific venture with highest international standard. Its shares may be freely traded in the international financial market. WONEC is to operate under auspices of the International Atomic Energy Agency (IAEA). WONEC by the nature of its policies, compositions, and adopted legal and ethical values can have the conditions and credibility to supply the world with nuclear energy and create public confidence in nuclear energy.

The research and development needed are to be performed by the participation of all the interested companies and research organizations of the world. It is to be done in a true spirit of international cooperation and service to humanity. Nuclear technology no longer is a monopoly of any single or group of nations and to various degrees most nations posses them. A new method of consultation and decision making process will be applied in order to safeguard the interest of all. The participants will not need to control WONEC to have their interests guaranteed. The project is to remain a totally scientific, industrial, and economic venture, avoiding dominating national politics, and remain in conformity with the spirit of the new age and the presently growing international desire for world peace.

The developing countries are expected to show great interest in participating in WONEC since in this way they will acquire nuclear power without the fear of being exploited by the vendors or making very large investments for an independent national nuclear program. The industrialized countries are expected to support the idea as well, since by participation in WONEC they will benefit from the sales of their technologies to WONEC and partake in a very large nuclear reactor sales market worldwide. Also the problem of nuclear proliferation that is of their great concern will be under control. The WONEC is to operate in the spirit of the new era providing the citizens of the world with clean and safe nuclear energy.

\section{Enabling technologies relevant to the nuclear installation.}

For the choice of utilization of coated particles as fuel, there is a need to develop the technology for the fabrication of $8 \mathrm{~mm}$ fuel elements from the coated particles. It must then be tested before and after irradiation. Since the irradiation involves small quantity of materials, it can easily be performed in various facilities available around the world. 
For the choice of using uranium dioxide fuel, the technology of fabrication of $8 \mathrm{~mm}$ spheres from UO2 powder needs to be developed. For initial stage, by grinding the cylindrical pellets produced for PWR, the spherical elements can be formed. Stamping out of zircaloy sheet hemispheres that can be welded together with the spherical fuel pellet put in between may do the cladding. The testing procedures are similar to that for PWR fuel fabrication.

\section{Status of R\&D and planned schedule}

The program of research and development of FBNR visualizes the following steps:

- Preparation of the conceptual design of the chosen option or options.

- Construction of a full size non-nuclear hydraulic module to verify the hydraulics behavior and determine the basic parameters.

- Realization of neutronics, thermal hydraulics, and structural calculations.

- Fabrication and testing of the fuel necessary for the nuclear experiment.

- Engineering design of the prototype of the reactor.

- Performance of a zero power experiment with one module in a nuclear experimental facility.

- Construction of the single module prototype.

A preliminary program for research and development of the Fixed Bed Nuclear Reactor (FBNR) concept, within and based on the scope of the Co-ordinated Research Project on Small Reactors Without On-site Refuelling is defined below.

8.1 Comprehensive coordinated study of long-life cores for small reactors of various types with a focus on the issues posed by extended fuel burn-up.

Inter-comparison of computer codes for neutronics, thermal-hydraulic, safety and mechanical design qualification of small reactor cores with extended burn-up of fuel.

8.1.1 Basic studies on the fuel type and method of securing reserve reactivity.

8.1.2 Study of the integrity of the fuel and cladding materials at very high fuel burnup using coated particle fuel.

8.1.3 Study of the fuel enrichment requirements within the scope of nuclear nonproliferation considerations.

8.1.4 Study of the method of securing reserve reactivity by fresh fuel insertion and utilization of burnable poison.

8.1.5 Neutronics calculations of FBNR.

8.1.5.1 Neutronics modeling and the choice of computer codes for the reactor core composed of fuel elements made from coated particles.

8.1.5.2 Criticality calculations.

8.1.5.3 Burnup calculations.

8.1.5.4 Kinetics calculations.

8.1.6 Thermal-Hydraulics calculations of the FBNR core.

8.1.6.1 Thermal hydraulics modeling and the choice of computer codes for the reactor core composed of fuel elements made from coated particles cooled by water. 
8.1.6.2 Calculations of fuel and coolant temperatures under different operating conditions.

\subsubsection{Safety Evaluation}

8.1.7.1 Safety analysis under various accident scenarios including loss of coolant accident, loss of flow accident, loss of power accident, anticipated transient without scram, and the safety against terrorist's actions.

\subsubsection{Structural Calculations}

8.1.8.1 Calculation of the thickness of the tubes that compose the core and the fuel chamber.

8.1.8.2 Calculation of the structures that support the reactor modules.

\subsubsection{Conceptual Design}

A 3-dimensional design of the reactor concept is to be created using one of the existing computer assisted design codes such as Pro-Engineer Wild Fire.

\subsection{Hydraulics study of the fixed bed suspended core concept.}

The IAEA Consultants participating in a Consultancy Meeting on Small Reactors without On-site Refuelling (March 2004), comment on the FBNR the followings: "In particular, the Consultancy noted that the innovative approach proposed in the Fixed Bed Nuclear Reactor (FNBR) concept (Federal University of Rio Grande Do Sul, Brazil) relating to hydraulically supported column of spherical fuel elements offers a good potential to serve as a method of passive control of core reactivity. This concept needs to be further developed and polished for its possible implementation in small reactors."

Therefore, a full size experimental hydraulic module made of transparent materials using stainless steel balls to simulate fuel elements is to be constructed. The module is to be provided with instrumentations to measure the basic hydraulics parameters such as pressure drop as a function of coolant flow velocity under different core configurations. Videotape is to be made of the operation in order to analyse the core behaviour under various simulated operational and accidental conditions.

8.3 Comparative assessment of passive reactivity regulating systems.

8.3.1 Study of the various forms of reactivity control are to be made such as using fine control rod in the centre of the module, use of absorber shell insertion, fixed bed level limiter, coolant pump flow controller, or using the coolant valve flow controller option.

8.4 Comparative assessment of several passive decay heat removal systems.

8.4.1 Study of passive cooling of fuel chamber being cooled by natural convection to air.

8.4.2 Study of fuel chamber being cooled by natural convection to water.

8.4.3 Study of the fuel in the fuel chamber being cooled by the water from an accumulator.

8.5 R\&D on coated particle type fuel for water-cooled reactors. 
8.5.1 Determination of the optimum size of the fuel element made from the coated particles for utilization in FBNR.

8.5.2 Method of fabrication of the large (about $8 \mathrm{~mm}$ ) diameter fuel elements from coated particles.

8.5.3 Testing of the irradiated and non-irradiated fuel elements.

\subsection{Participation of various countries around the world.}

There are many institutions in many countries that are showing interest in participating in the project. There are many financial sources and possibilities around the world that can be utilized. For example, if at least 3 European countries take part in the project, the European Community will contribute with $50 \%$ of the cost. Many countries subsidize their clean energy related projects up to $60 \%$. Others provide funds for research that will help elevate the level of science and technology in their countries. There exist many visionary private investors who may provide risk capitals. The nuclear industry and research institutions can make investments by supplying equipments, use of their facilities, manpower, and technology. In this manner, the necessary funds can be raised.

As an example using the mentioned possibilities, an investment of $\$ 1$ by the investor in country $\mathrm{Ci}$ attracts $\$ 1.50$ from the government and thus results in $\$ 2.50$ for the project. With the contribution of the European Community, it becomes $\$ 5.00$. If 20 countries participate in this scheme, $\$ 100,00$ becomes available for the project. Therefore, the investment of only $\$ 10,000.00$ each by 20 institutions from industry, research centers, or private investors can raise $\$ 1,000,000.00$ for the research and development of the project. The investments can be in the form of service, equipment, or money.

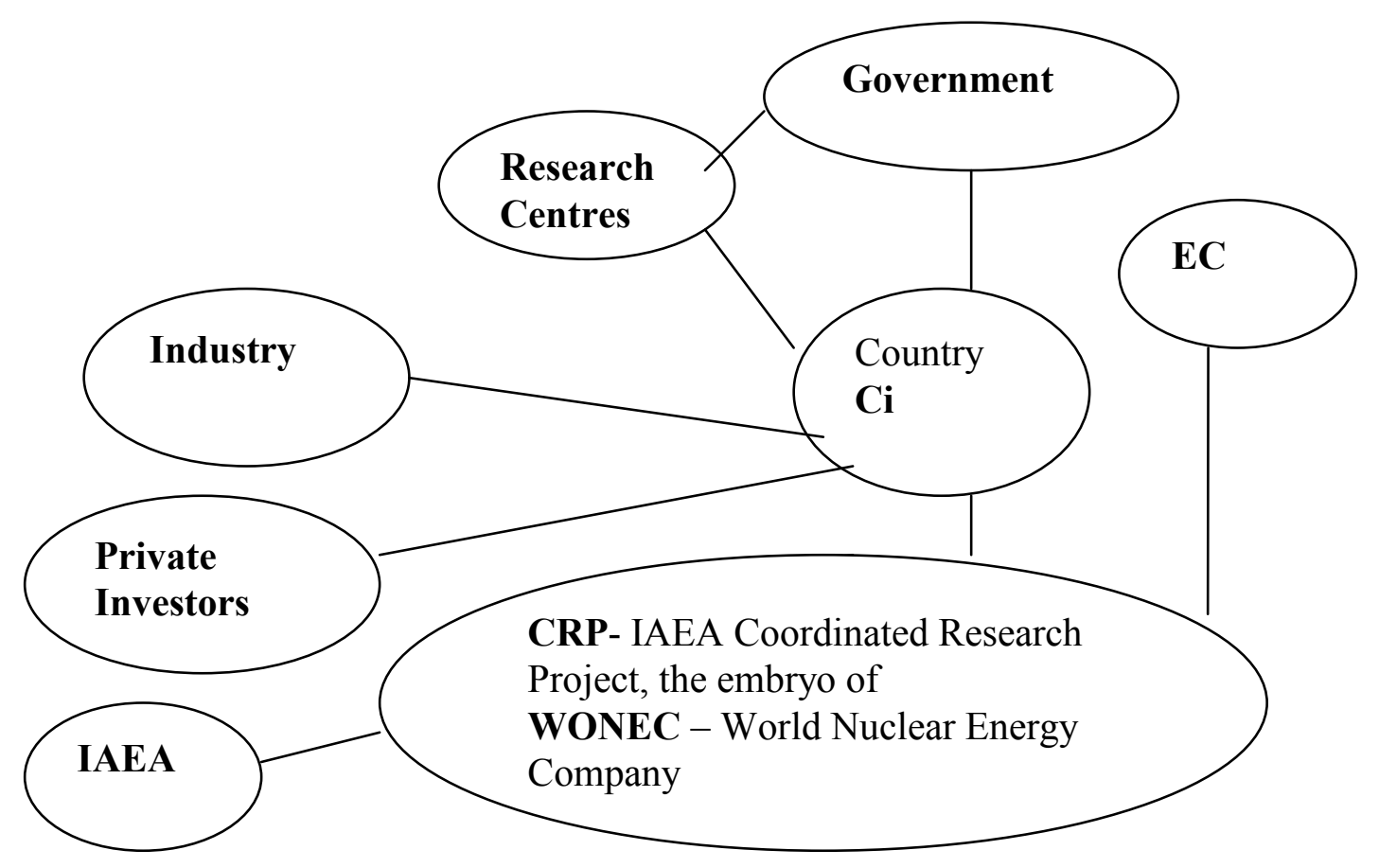




\section{Demonstration prototype}

A non-nuclear experiment is needed to be performed to observe the hydraulic behaviour of the system. Therefore, a full size experimental hydraulic module made of transparent materials using stainless steel and or lead balls to simulate fuel elements need to be constructed. The module should be provided with instrumentations to measure the basic hydraulics parameters such as pressure drop as a function of coolant flow velocity under different core configurations. A videotape is to be made of the operation in order to analyse the core behaviour under various simulated operational and accidental conditions.

\section{Other similar design activities.}

There are similar activities going on in Russia at the All-Russian Nuclear Machinery Institute (VNIIAM) in Moscow, and in the United States at the Battelle, Pacific Northwest National Laboratory (PNNL). It concerns the development of pebble bed boiling water reactor concept with superheated steam [79]. A nuclear reactor with micro fuel element (MFE) cooled and moderated by water is proposed. The reactor supplies energy to a $1500 \mathrm{MWe}$ plant. The water in the reactor pressure vessel is at $16 \mathrm{MPa}$ pressure and $550 \mathrm{C}$ temperature that allows a steam cycle thermal efficiency of $43 \%$.

\section{References}

1) Sefidvash, F. "Preliminary evaluation of the fixed and fluidized bed nuclear reactor concept using the IAEA-INPRO methodology", Kerntechnik, 69 (2004) 3, 01-06, February 2004.

2) Sefidvash, F. "Fixed Bed Suspended Core Nuclear Reactor Concept", Kerntechnik, 68 (2003) 5659, February 2003.

3) Sefidvash, F. "Fixed Bed Nuclear Reactor Concept", International Conference on Innovative Technologies for Nuclear Fuel Cycles and Nuclear Power, Vienna, Austria, 23-26 June, 2003.

4) Sefidvash, F., "Fluidized Bed Nuclear Reactor as a IV Generation Reactor, PHYSOR 2002 International Conference on the New Frontiers of Nuclear Technology: Reactor Physics, Safety and High-Performance Computing, Seoul, Korea, October 7-10,2002.

5) Oliveira, C. I., Sefidvash, F., "Análise Térmica do Reator Nuclear a Leito Fluidizado", International Nuclear Atlantic Conference - INAC 2002, Rio de Janeiro, Brazil, August 11-16, 2002.

6) Sefidvash, F., "Fluidized Bed Nuclear Reactor proposed for the Generation IV Reactors, International Nuclear Atlantic Conference - INAC 2002, Rio de Janeiro, Brazil, August 11-16, 2002.

7) Sefidvash, F., Mohamad, A. A., "Passive Cooling Characteristics of the Fluidized Bed Nuclear Reactor", First International Conference on Applications of Porous Media, Jerba, Tunisia, June 02-08, 2002.

8) Sefidvash, F., Seifritz, W., "An Energy Amplifier Fluidized Bed Nuclear Reactor Concept", Kerntechnik 66 (2001) 1-2, pp.59-61

9) Sefidvash, F.; Van der Laan, F.; Borges, V.; Cornelius, V., "Estudo do comportamento de 
fluidização usando método de visualização do fluxo" XII ENFIR - Encontro Nacional de Física de Reatores e Termohidráulica. Rio de Janeiro, Brasil, October 15-20, 2000,

10) Sefidvash, F., "The Fluidized Bed Nuclear Heat Reactor Concept", International Conference \& Exhibition on Industrial Heat Engineering, May 24-30, 1999, Kiev, Ukraine.

Also published in the journal of Industrial Heat Engineering, vol.21, no.4, 1999. Begell house Inc. Publishers, New York, USA, ISSN 0204-3602.

11) Sefidvash, F., " The Generalized Formulation for Evaluation of Fluidized Bed Nuclear Reactor Concept", sent for publication to Kerntechnik, 1999.

12) Sefidvash, F. "Water Desalination by Fluidized Bed Nuclear Reactor", being published in Kerntechnik, 64 (1999)0 pp1-5.

13) Sefidvash, F., Seifritz, W., "An Energy Amplifier Fluidized Bed Nuclear Reactor Concept", being published in Kerntechnik, 1999.

14) Sefidvash, F., "A New Advanced Safe Nuclear Reactor Concept”, 15th Brazilian Congress of Mechanical Engineering (COBEM99), November 22-26, 1999, Aguas de Lindoia, São Paulo, Brazil.

15) Sefidvash, F., “ A Solution to Nuclear Power Problem”, International Joint Meeting of Latin American Section of the American Nuclear Nuclear Society (LAS/ANS) and Sociedad Nuclear Mexicana, July 18-21, 1999, Acapulco, Mexico.

16) Sefidvash, F., Seifritz, W., "An Energy Amplifier Using Fluidized Bed Nuclear Reactor Concept", Nuclear Applications of Accelerator Technology, Nov.16-20, 1997, Albuquerque, New Mexico.

17) Sefidvash, F. "A High Efficiency Fluidized Bed Nuclear Reactor Cooled by Supercritical Steam”, XI ENFIR, Hotel Palace, Poços de Caldas, MG, 18-22 de agosto de 1997.

18) Seifritz, W. Sefidvash, F. "Non-Linear Noise Theory for the Fluidized Bed Light Water Reactor" Kerntechnik, 62, (1997), 4, pp178-183.

19) Sefidvash, F., "Advancement in the Fluidized Bed Nuclear Reactor Concept", The Eight International Conference on Emerging Nuclear Energy Systems, Obninsk, Russia. June 24-28, 1996.

20) Sefidvash, F., "Status of the Small Modular Fluidized Bed Light Water Nuclear Reactor Concept", Nuclear Engineering and Design, 167 (1996) 203-214,1996.

21) Sefidvash, F. , Borges, V., "Reator Nuclear a Leito Fluidizado Como Formador de Pessoal", VI Congresso Geral de Energia Nuclear (CGEN),Rio de Janeiro, Brasil, 27 de outubro a 1 de novembro de 1996.

22) Rossetti, M.M., V. Borges, F. Sefidvash, "Estudo da Homogeidade do Núcleo de um Reator Nuclear a Leito Fluidizado e Determinação de Parâmetros Básicos”, VIII Salão de Iniciação Científica, UFRGS, 9 a 13 de setembro de 1996.

23) Sefidvash, F. \& Elbern, A. "The Study of Transients in the Fluidized Bed Nuclear Reactor by Linkage and Fuzzy Methods" The Third International Conference on Nuclear Engineering (ICONE-3), Kyoto International Convention Center, Kyoto, Japan. April 23-27, 1995.

24) Sefidvash, F. "A Direct Cycle Fluidized Bed Nuclear Reactor Operating at Supercritical Pressure", Technologies for Energy Efficiency and Environmental Protection Conference, Cairo, Egypt, March 26-30, pp.47-50, 1995.

25) Sefidvash, F., "A preliminary Thermal-Hydraulic Study of the Fluidized Bed Nuclear Reactor Concept" Kerntechnik, Vol.60, No.1, pp.48-51, February 1995.

26) Sefidvash, F., "Emerging Nuclear Reactors" Workshop on Reactor Physics, Design and Safety, International Centre for Theoretical Physics (ICTP) April, 1994. 
27) Sefidvash, F. "Un Reator Nuclear Simple y Seguro al Servicio de la Humanidad", ECOEcología y Unidad Mundial, Año 2, No.7, P.23, 1994.

28) Sefidvash, F. "Nuclear Energy in the Next Century" Second European Congress on Economics and Management of Energy in Industry, 5-9 April 1994, Estoril, Portugal.

29) Sefidvash, F. "The Structural Design Needs of a Small Modular Fluidized Bed Nuclear Reactor", 12th International Conference on Structural Mechanics in Reactor Technology, August 15-20, 1993, Stuttgart, Germany. Vol. SD-1, pp.261-266.

30) Sefidvash, F., "Preliminary Thermal Hydraulic Analysis of a Fluidized Bed Nuclear Reactor Concept", ASME/AIChE/ANS/AIAA National Heat Transfer Conference, Atlanta Georgia. . August 8-11, 1993. ANS Proceedings, Vol.7, pp.378-382.

31) Sefidvash, F., "A Small Modular Fluidized Bed Nuclear Reactor", International European Nuclear Society Topical Meeting Towards the Next Generation of Light Water Reactors. The Hague, Netherlands, April 25-28, 1993.

32) Borges,V., Sefidvash, F. "Metodos Operacionais de Reator Nuclear a Leito Fluidizado", IX Encontro Nacional de Física de Reatores Nucleares e Termo-hidráulica. Caxambu, MG. 25-29 de outubro de 1993.

33) Borges,V., Sefidvash, F. "Termohidráulica do Reator Nuclear a Leito Fluidizado", IX Encontro Nacional de Física de Reatores Nucleares e Termo-hidráulica. Caxambu, MG. 25-29 de outubro de 1993.

34) Sefidvash, F. "An Experimental Method to Study the Porosity of a Fluidized Bed Using Gamma Ray Transmission Technique", 45 Reunião Anual da Sociedade Brasileira para o Progresso da Ciência, Recife, PE, 11-16 de Julho de 1993. Vol.1, pp.203.

35) Fisher, R., Sefidvash, F. "Estudo de Queima de Combustivel no Reator Nuclear a Leito Fluidizado", V Salão de Iniciacão Cientifíca, UFRGS, 4 à 8Outubro 1993.

36) Fischer, R., Sefidvash, F. "Estudo de Comportamento Cinético de um Reator Nuclear a Leito Fluidizado", IV Salão de Iniciação Científica, UFRGS, Outubro 26-30.1992. Vol.1, no.119.

37) Sefidvash, F., "The Future of Nuclear Energy", 4 Congresso Geral de Energia Nuclear, Rio de Janeiro, 5-10 de Julho de 1992. vol.2, pp 879-883.

38) Sefidvash, F., "Nuclear Energy and the New Era", Proceedings of the International Specialists' Meeting on Potential of Small Nuclear Reactor for Future Clean and Safe Energy Sources. Tokyo, Japan, October 23-25, 1991.

39) Vilhena, M.T., Sefidvash, F., "Solution of the Heat Conduction Equation for a Fluidized Bed Nuclear Reactor", Kerntechnik, vol.55, no.2, pp 108-111, 1990.

40) Borges, V., Sefidvash, F., "Método de Cálculos neutronicos de uma Célula Esférica Equivalente a uma Cilindrica, para Utilização de Códigos Computacionais para Reatores a Água Leve no Reator Nuclear a Leito Fluidizado", VII Encontro Nacional de Física de Reatores Recife, 26-28 Abril, 1989.

41) Sefidvash, F., "An Inheerently Safe Small Nuclear Reactor Concept", Proceedings of the American Nuclear Society International Topical Meeting on Safety of Next Generation Power Reactors, Seattle, Washington, USA, May 1-5, 1988.

42) Sefidvash, F., "Um Novo Conceito de reator Nuclear", Anais da 39a. Reunião Anual da Sociedade Brasileira para o Progresso da Ciência, 12-18 julho 1987, Brasilia, DF.

43) Sefidvash, F., Johansson, M. "Desenvolvimento de um Código Computacional para o Cálculo de Temperaturas no Reator Nuclear a Leito Fluidizado", Relatorio p/ CNPq, Processo No. 404870/84NU, 1987.

44) Sefidvash, F.,Borges, V., "Desenvolvimento de um Código Computacional para o Cálculo de 
Célula, com Queima para um Reator Nuclear a Leito Fluidizado" Relatorio p/ CNPq, Processo No. 408770/85NU, 1987.

45) Sefidvash, F., Streck, E., Borges, V., "Cálculo de Queima de um Combustível ( burnup) para um Reator Nuclear a Leito fluidizado", Relatorio p/ CNPq, Processo No. 408848/85NU, 1987.

46) Sefidvash,F. e onze participantes do Projeto Colméia - "Estudo de Viabilidade do Conceito de Reator Nuclear a Leito Fluidizado", Relatório p/ FINEP - Vols. 1, 2 e 3, 1987.

47) Vilhena, M.T., Sefidvash, F., "Análise de Transferência de Calor em Regime Transiente em Reator Nuclear a Leito Fluidizado Ütilizando a Transformada de Laplace", Anais do I Simpósio Brasileiro de Transferência de Calor e Massa", 1-3 jullho 1987, Campinas, SP.

48) Sefidvash, F., Vilhena, M.T., Streck, E., Borges, V., Johansson, M., "State of Art of the Fluidized Bed Nucleaar Reactor Concept", Anais do IV Congresso Brasileiro de Energia, Rio de janeiro, RJ, 17-21 agosto 1987.

49) Sefidvash, F., "Transient Heat Tranfer in a Fluidized Bed Nuclear Power Reactor", II Congresso Latinoamericano de Transferência de Calor e Matéria, São Paulo 12-15 de maio (1986).

50) Sefidvash, F., "Um Conceito de Reator Nuclear a Leito Fluidizado", Anais do I Congresso Geral de Energia Nuclear, Vol. 1, pp. 333-337, Rio de Janeiro, Março (1986).

51) Schaefer, L. and Sefidvash, F., "Fabricação de revestimentos dos Elementos de Combustível para o Reator a Leito Fluidizado", Anais III Congresso Brasileiro de Engenharia e Ciência dos Materiais, Florianópolis, Sc, 10-12 dezembro (1986).

52) Sefidvash, F., "Problemas Matemáticos do Reator Nuclear a Leito Fluidizado", Boletim da Sociedade Brasileira de Matemática Aplicada e Computacional (SBMAC), Vol. 5, No. 3, dezembro (1985).

53) Sefidvash, F., "A fluidized Bed Nuclear Reactor Concept" , Nuclear Technology, Vol. 71, No. 3, pp. 527-534 (1985).

54) Sefidvash, F., "Reator Nuclear a Leito Fluidizado - Tecnologia para os Dias de Hoje", Boletim da Sociedade Brasileira de Matemática Aplicada e Computacional (SBMAC), Vol. 5, No. 3, dezembro (1985).

55) Sefidvash, F., "A Simple, Small, Safe Nuclear Reactor for Developing Countries", Proceedings of II International Course on Nuclear Physics and Reactor, Bogotá, Colômbia, February (1985).

56) Sefidvash, F., "A Small Safe Noclear Power Reactor", Proceedings of the III Congresso Brasileiro de Energia, Rio de janeiro, October (1984).

57) Haroon, M.R., Sefidvash, F., "Reactor Physics Study of Organic Moderated Fluidized Bed Nuclear Reactor", Journal of Natural Science and Mathematics, Vol. 24, No. 1, pp. 129-146, April (1984).

58) Sefidvash, F., "Loss of Coolant Accident in the Fluidized Bed Nuclear Power Reactor" Atomkernenergie/Kerntechnick, Vol. 42, No. 2, pp. 125-126 (1983).

59) Sefidvash, F., João R.L. de Mattos, Ligia M.M. Eberle, Marco T.M.B. de Vilhena, Lirio Shaefer, Luiz F.C. Degrazzia, Edsin Z. Silva, Jorge E.M. Ramsy e Athur B.P. Machado, "Relatório do Progresso Alcançado na Pesquisa e Desenvolvimento de um Reator Nuclear a leito Fluidizado", IV Encontro Nacional de Física de Reatores, Centrecom, Itaipava, Rio de Janeiro, novembro (1983).

60) Sefidvash, F., "Um Reator Brasileiro", Universidade Ano 1, No. 3, pp. 3-7 (UFRGS) (1983).

61) Sefidvash, F., "A Nuclear Power Reactor for Developing Countries", Proceedings of the First International Course of Reator Physics for Developing Countries, Bogotá, Colômbia (1983).

62) Sefidvash, F., "Pesquisa e Desenvolvimeto de um Novo Reator Nuclear Para o Brasil", Revista 
Brasileira de tecnologia, Vol. 14, No. 1, jan/fev (1983).

63) Sefidvash, F., Mattos, J.R.L., "Estudo de Viabilidade de um Reator de Pesquisa a Leito Fluidizado para a UFRGS". Relatorio DENUC/UFRGS, 1983.

64) Sefidvash, F., "Estudo Experimental do Comportamento termo-hidraulico de Leito Fluidizado com Geração de Calor e Mudança de Fase", CNPq, 1983.

65) Sefidvash, F.,"Physics and Thermal and Hydraulics of the Fluidized Bed Nuclear Power Reactor", II Encontro Nacional de Fisica de Reatores - Centrecom, Itaipava, Rio de Janeiro, dezembro 12-14 (1982).

66) Sefidvash, F., "Heat Transfer in a Fluidized Bed Nuclear Power Reactor", I Congresso Latinoamericano de Transferencia de calor y Materia, La Plata - Republica Argentina, 31 de Octubre al 4 de Noviembro (1982).

67) Sefidvash, F., "Reator de Leito Fluidizado", Relatorio p/ CNEN, 1981-82.

68) Sefidvash, F., "International Cooperation Through Design and Development - An Invitation", International Center of Theoretical Physics Publication No. SMR/93-11-10(1982).

69) Sefidvash, F., "Preliminary Thermal Design Calculation of the Fluidized Bed Nuclear Power Reactor", Atomkernenergie/Kerntechnik, Vol. 41, No. 1, pp. 45-49, (1982).

70) Sefidvash, F., "Reator Nuclear a Leito Fluidizado", Relatorio para Commissão Nacional de Energia Nuclear (CNEN), Brasil, 1980.

71) Sefidvash, F., "Estudo da Viabilidade de um Reator Nuclear para o Brasil sob o Ponto de Vista Termohidraúlico", Relatorio p/ CNPq, 1980.

72) Sefidvash, F., "A Nuclear Power Reactor Concept for Brazil", Revista Brasileira de Tecnologia, Vol. 11, No. 3, pp. 145-158 (1980).

73) Sefidvash, F., Haroon, M.R., "Preliminary Reactor Physics Calculations of a Fluidized Bed Nuclear Reactor Concept", Atomkernenergie/Kerntechnik, Vol. 35, No. 3, pp. 191-195 (1980).

74) Sefidvash, F., "A Nuclear Power Reactor Concept for Iran", Iranian Journal of Science and Technology (Pergamon Press) Vol. 7, pp. 147-149 (1978).

75) Sefidvash, F., "Nuclear Power Plant for Iran", Proc. of the Mechanical Engineering Congress with Emphasis on Enegy, Shiraz (1974).

76) OKA, Y., et al., Systems Design of Direct-Cycle Supercritical Water-Cooled Fast Reactors, Nuclear Technology, .109 (1995).1-10.

77) Borges, V., Vilhena, M.T., "Dynamic Stability of a Fluidized-Bed Nuclear Reactor", Nuclear Technology, Vol.III, August 1995.

78) Harms, A.A., Bilanovic, Z., Eskandari, M.R., "Intrinsic Fission Excursion Inhibition With Tandem-Isotope Temperature Triggers", Fusion Technology, 20(1991)602-604.

79) Tsiklauri, G., Newman, D., Meriwether, G., Korolev, V, Filippov, G, Bogoyavlensky, R.R., "Pebble Bed Boiling Water Reactor Concept with Superheated Steam". ICONE-22058 $10^{\text {th }}$ International Conference on Nuclear Engineering, Arlington, Virginia, USA, April 14-18, 2002 , 


\section{Appendix A : Design Descriptions}

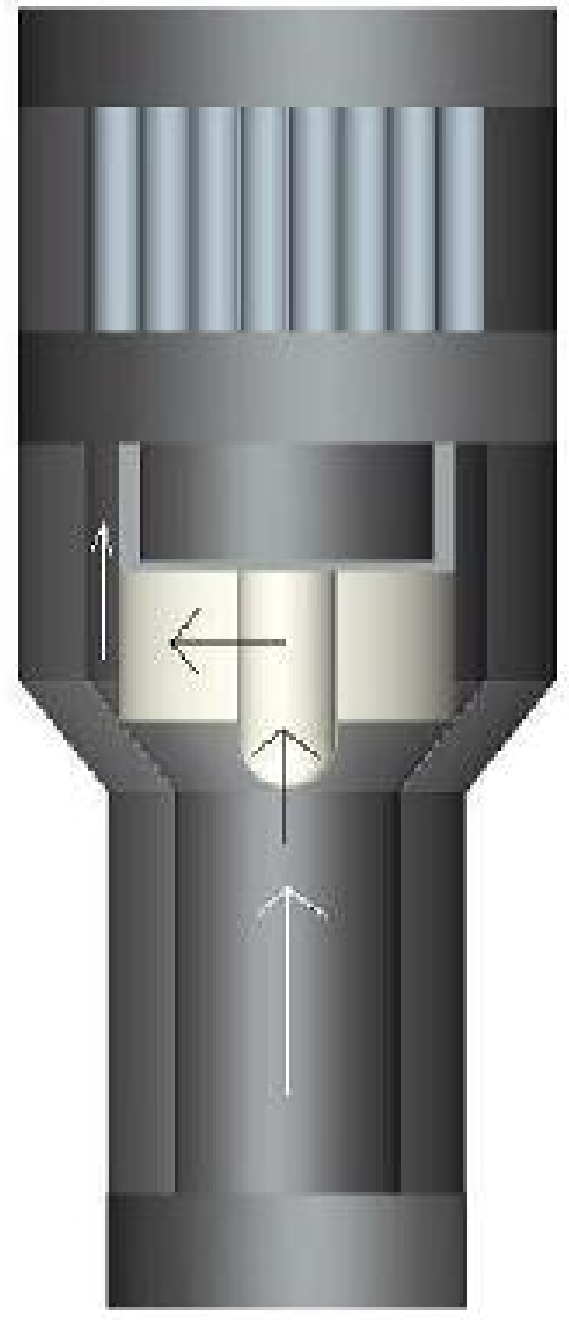

Single Module: The pressurized water flows upward through the fuel chamber made of highly neutron absorbing alloy. Then it enters the core of the module. In the core, the coolant flows horizontally passing the walls of the two perforated central tubes, which hold the fuel elements between them. After absorbing heat in the core, it flows upward into the steam generator. The steam generator is an integrated heat exchanger of shell and tube type. Then the coolant returns down the outer space between the outer hexagonal tube and the core tube back to the pump and distributor. The core level limiter defines the height of the core. The absorber shell sliding up and down the core tube acts as a fine control rod. For detailed description see www.rcgg.ufrgs./fbnr 


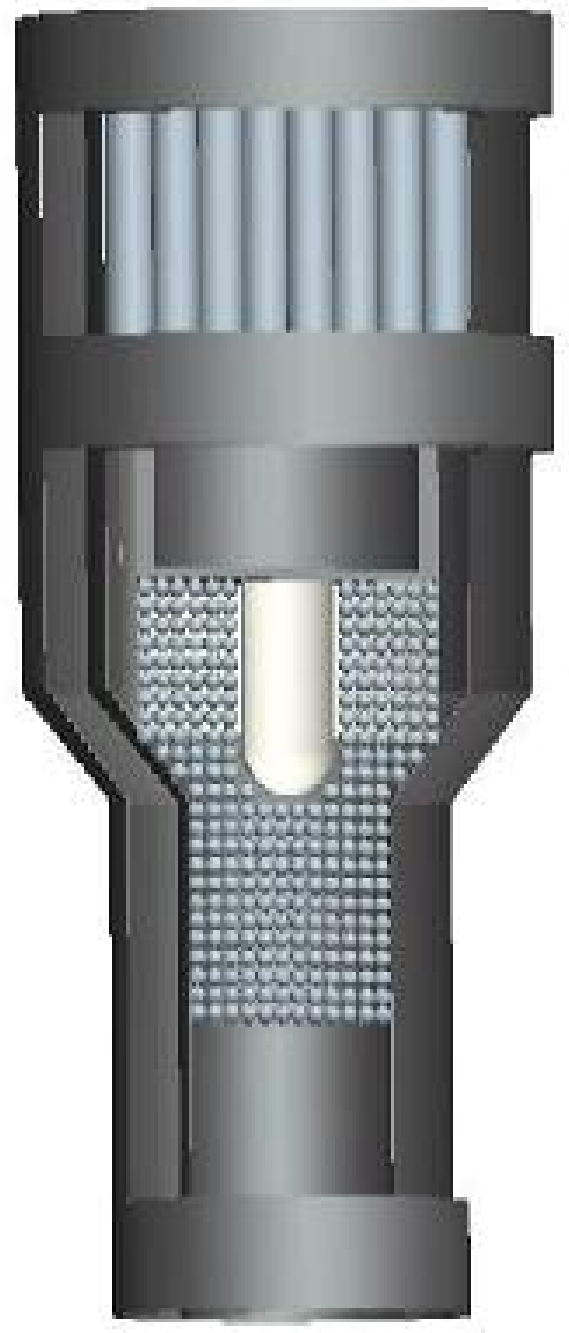

Operating condition: The spherical fuel elements are out of the fuel chamber and are in the core. The core level limiter is adjusted allowing sufficient fuel elements enter the core in order to have the reactor in the critical condition. The reserve reactivity is contained in the extra fuel elements that are left in the fuel chamber outside the core. 


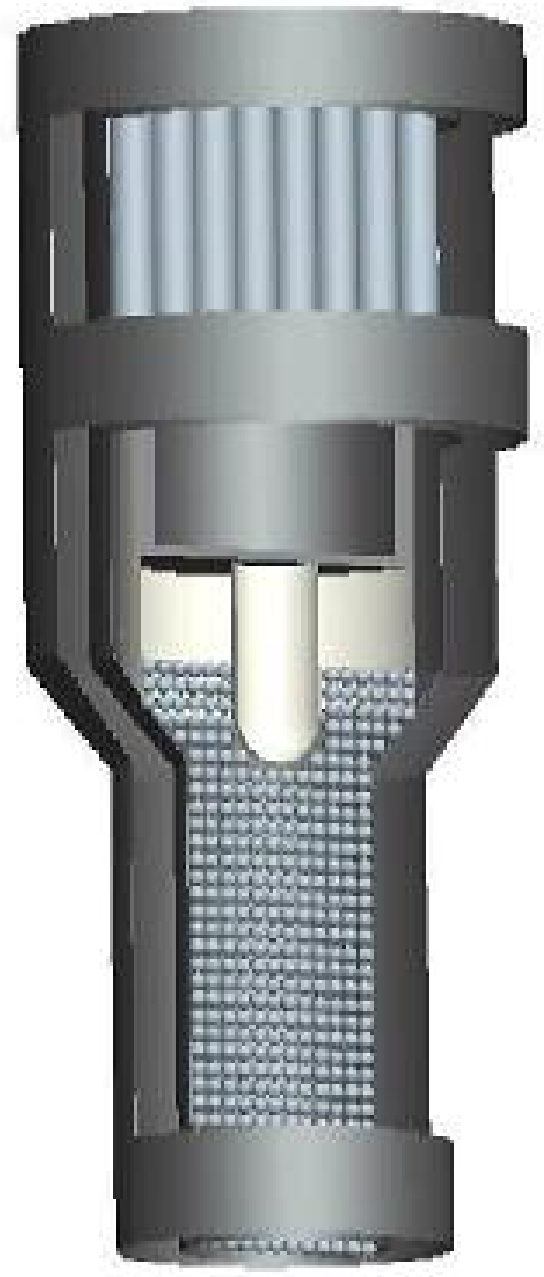

Shut down or accident conditions: The pump is turned off automatically; therefore, the fuel elements fall out of the reactor core into the fuel chamber through the force of gravity. 


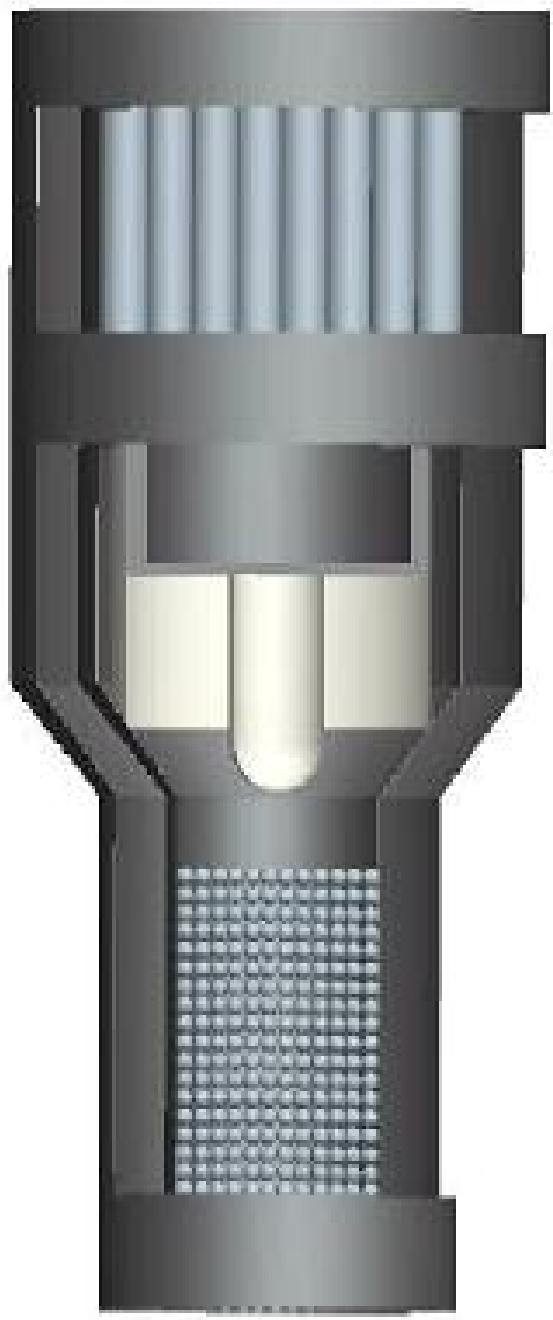

Shut down condition: The core is empty and the fuel elements are stored in the passively cooled fuel chamber under a highly subcritical condition. The decay heat is dissipated through natural convection. 